\title{
THE EFFECT OF RURAL SETTLEMENT LANDSCAPE PATTERN ON WATER CONSERVATION IN XINBIN COUNTY, CHINA
}

\author{
QI, L. ${ }^{1,2,3}-$ LI, N. ${ }^{4^{*}}-$ HAN, J. C. ${ }^{1,2,3}-$ WANG, H. Y. ${ }^{1,2,3}$ \\ ${ }^{I}$ Shaanxi Provincial Land Engineering Construction Group Co., Ltd., Shaanxi Key \\ Laboratory of Land Consolidation, Xi'an 710075, China \\ ${ }^{2}$ Institute of Land Engineering and Technology, Shaanxi Provincial Land Engineering \\ Construction Group Co., Ltd., Xi'an 710075, China
}

${ }^{3}$ Shaanxi Provincial Land Consolidation Engineering Technology Research Center, Xi'an 710075, China

${ }^{4}$ Beijing Huayuan Thick Soil Land Planning and Design, Beijing 100193, China

*Corresponding author

e-mail:wdlndudu@163.com

(Received 25 ${ }^{\text {th }}$ Apr 2019; accepted 11 $1^{\text {th }}$ Jul 2019)

\begin{abstract}
Rural settlements are not only the main form of Chinese farmer residence, but also a space for rural production, living as well as other comprehensive functions, being an important part of rural land use. The impact of rural settlement changes on soil and water conservation is studied as it is of great significance for soil and water conservation. Based on the satellites of Xinbin County in 1992, 2001 and 2010, this study analyzes the distribution characteristics of rural settlements by using ArcGIS software spatial analysis function and landscape index method. At the same time, SPSS software is used to analyze the correlation between soil erosion and the size of rural settlements. The results show that soil erosion is positively correlated with rural settlement size and population density. The rural residential areas in Xinbin County are severely fragmented with scattered layout. Soil erosion shows a decreasing trend while increasing in distance from settlements. The bigger the scale, the more serious the erosion.
\end{abstract}

Keywords: soil erosion, landscape index, rural habitat, ecological protection, China

\section{Introduction}

Rural settlements are the most significant form of human settlement (Zhou et al., 2013). It has a footprint that interacts with the surrounding social economy, the natural environment and the people. Its layout, form and scale have undergone several major changes (Xi et al., 2018; Yang et al., 2016; Yang, 2015). Although Chinese urbanization level has been greatly improved (Chaolin et al., 2017), the agricultural population quantity is still large. In the future, rural settlement lands will still be an important part of Chinese rural-urban construction land use. Meanwhile, it is still the main form of living for rural populations. There is no overall planning for the layout of rural settlements in most parts of China. Besides, the lack of effective supervision and management of the land result in the spatial layout dispersal (Chen, 2017; Guo et al., 2012). The rural residents have always chosen their settlements spontaneously. Due to the limitations of traditional culture and the natural environment and in order to facilitate the production of farming, the distribution of rural settlements is very fragmented in the mountain areas. This form of layout not only makes it more difficult for farmers to travel, but also negatively affects the natural ecological environment of the mountainous areas, especially the water conservation function in there. The Liaodong mountainous area refers to the mountainous and hilly areas 
of 32 counties in the eastern part of Liaoning province, China, including the counties of Benxi, Fushun, Anshan, Tieling and Dandong. As the main water source conservation area and green barrier area in the Liaohe Plain, the Liaodong mountainous area provides $83 \%$ of the province's water supply. The mountainous areas of eastern Liaoning should not only meet the current needs of people for production and life, but also offer ecological security and water resources for the future economic development of Liaoning Province. The third remote sensing survey of soil erosion in Liaoning Province shows that the soil erosion area in the mountainous areas of eastern Liaoning was $1626.27 \mathrm{~km}^{2}$, accounting for $25.2 \%$ of the total area, $35 \%$ of the total area of soil erosion in the province. This indicates that there are still potential threats to the water conservation function in the mountainous areas of eastern Liaoning. As one of the important water conservation areas, the areas of eastern Liaoning, Xinbin County where its residents are active is the source of the Hunhe River and belongs to the mountainous area (Ma et al., 2014; Ying, 2017). Therefore, both the protection of water conservation functions by increasing natural vegetation and the adverse effects of human activities on water conservation caused by the layout of rural settlements should be considered. This paper analyzes the distribution features, landscape pattern and soil erosion characteristics of rural settlements in Xinbin County (Christensen et al., 2016; Remmel et al., 2017). From a unique perspective, the influence of the evolution of rural settlement landscape pattern on water conservation function is explored. Based on the discussion of the soil erosion status and the spatial characteristics of residential distribution in the three time periods of Xinbin County, this paper researches the distribution features of residential areas affecting soil erosion, and discusses the coupling relationship between rural residential area distribution and water and soil erosion. Through this study, it provides a scientific basis for optimizing the layout of rural residential areas in ecological protection areas and promoting regional water resources protection.

\section{Methodology and data}

\section{Research method}

Using four methods - the fusion classification, supervised classification, partition classification and visual interpretation, the SPOT and Landsat data are extracted by ENVI4.5 and ArcGIS software (Maguire, 2015; Ju et al., 2016; Ke, 2016).

Based on the land use data of Xinbin County, the superposition analysis is carried out with the support of ArcGIS software. The landscape index are selected at the plaque level (Rodríguez-Loinaz et al., 2015; Chen et al., 2018), including number of plaques (NP), total plaque area (TA), area-weighted average plaque fractal dimension (AWMPFD), plaque density (PD), average plaque area (MPS) and dispersion (RC). Then, Fragstats 3.3 software is used to calculate the landscape index. Finally, SPSS software is used to analyze the correlation between soil erosion and rural settlement size, the structure of the rural settlements and population density (Green et al., 2016; Cronk, 2017).

\section{Data source and processing}

\section{Data source}

The research data is derived from the data of Landsat5TM in 1992, 2001 and 2010 of Xinbin County with a resolution of $30 \mathrm{~m} \times 30 \mathrm{~m}$, socio-economic data, the map of the status quo of 110,000 land use and the 1:10,000 topographic map. Among them, remote sensing data mainly uses 3 and 4 bands of data (Ying, 2017). 


\section{Data processing}

First, the 3-band and 4-band images are imported into ENVI4.5 software. Second, the Vectors option in the Overlay menu is selected to overlay the boundaries of the study area onto the image. Finally, the ROI Tool in the Region of Interest in the Tools menu and the Subset Data are selected via ROIs option in File in its dialog box, and the Background Value is set to 0, then is saved in a new folder. The other two data are processed in the same way. Next, normalized difference vegetation index (NDVI) and vegetation coverage (VFC) are calculated.

Before calculating NDVI (Gandhi et al., 2015), images of band 3 and band 4 need to be compressed into a layer. The specific operation process is open the 3 and 4 band image in ENVI 4.5 software and Layer Stacking is selected in Basic Tools. Then the dialog box of Layer Stacking Parameters appears. The Import Files button is clicked to output the 3 and 4 band image images, and then they are named. When the results are output, they should be saved in a fixed folder.

Next NDVI is calculated. The specific process is: import the image map of the compressed surface reflectivity into ENVI4.5 software, select band math in the Basic Tools drop-down menu. Input formula (Eq. 1), assign 4 channels of surface reflectivity to NIR, assign 3 channels of surface reflectivity to R, then name the output and save the result.

Using NDVI values, vegetation coverage is calculated by Equation 2.

$$
\begin{gathered}
N D V I=\frac{N I R-R}{N I R+R} \\
V F C=\left(N D V I-N D V I_{\text {min }}\right) /\left(N D V I_{\text {max }}-N D V I_{\text {min }}\right)
\end{gathered}
$$

\section{Making slope maps and soil erosion maps}

The DEM data is obtained from the spatial analysis tool of ArcGIS software to obtain the slope map (Allen, 2016).

According to the soil erosion index Table 1, the soil erosion map is obtained using the decision tree in ENVI software (Segatori, 2017). The map is shown in Figures 1, 2 and 3 .

Table 1. Ministry of Water Resources soil erosion indicators

\begin{tabular}{c|c|c|c|c|c|c}
\hline $\begin{array}{c}\text { Vegetation } \\
\text { coverage } \\
(\mathbf{\%})\end{array}$ & \multicolumn{5}{|c}{ Slope } \\
\cline { 2 - 6 } & $<\mathbf{5}^{\circ}$ & $\mathbf{5}^{\circ} \mathbf{8}^{\circ}$ & $\mathbf{8}^{\circ} \mathbf{\mathbf { 1 5 } ^ { \circ }}$ & $\mathbf{1 5}^{\circ} \sim \mathbf{2 5}$ & $\mathbf{2 5}^{\circ} \mathbf{3 5 ^ { \circ }}$ & $\mathbf{3 5}^{\circ}$ \\
\hline $\mathbf{7 5}$ & Microdegree & Microdegree & Microdegree & Microdegree & Microdegree & Microdegree \\
$60-75$ & Microdegree & Light erosion & Light erosion & Light erosion & Middle degree & Middle degree \\
$45-60$ & Microdegree & Light erosion & Light erosion & Middle degree & Middle degree & Serious erosion \\
$30-45$ & Microdegree & Light erosion & Middle degree & Middle degree & Serious erosion & Very intensive \\
$<30$ & Microdegree & Middle degree & Middle degree & Serious erosion & Very intensive & Severe erosion \\
\hline
\end{tabular}




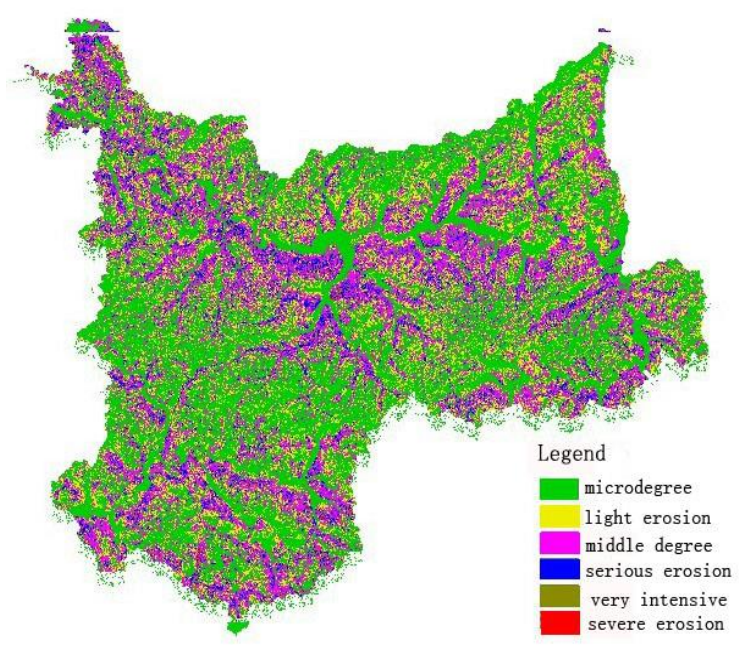

Figure 1. Soil erosion in 1992

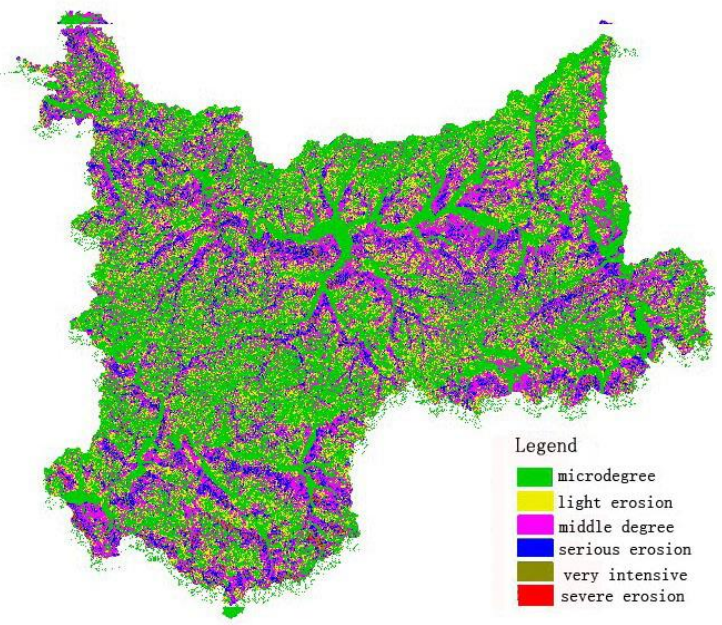

Figure 2. Soil erosion in 2001

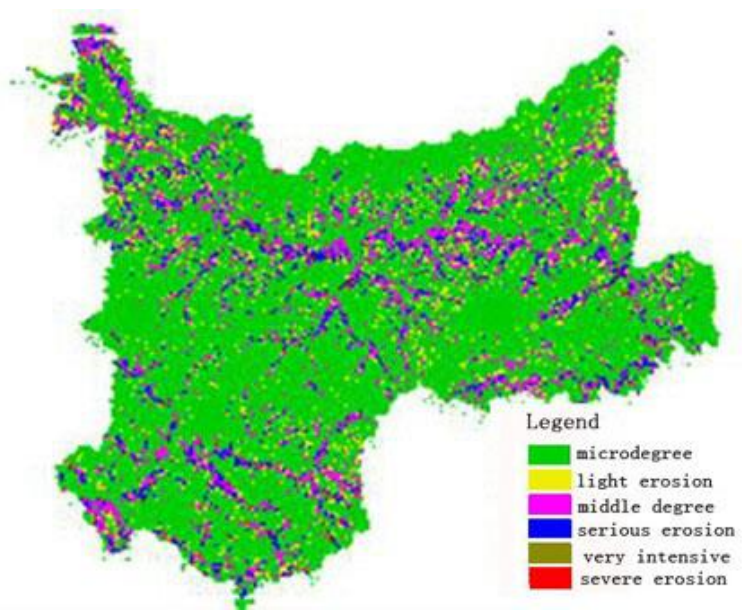

Figure 3. Soil erosion in 2010 


\section{Rural settlement data processing}

Combined with the overlay module in ArcGIS software, the rural settlement attribute data is superimposed with the elevation and slope related attribute data to calculate the spatial distribution characteristics of the rural settlement (Murasingh et al., 2018; Conrad et al., 2015). The number of rural settlements is measured using statistical data, combined with field surveys. The field research is mainly carried out on-site verification of the population data in the form of a symposium in 2013 to correct the statistical data. According to the density of rural settlements, the distance and mutual influence between rural settlements are considered. Then, the analysis of rural settlements is buffered. A buffer at a distance of $1000 \mathrm{~m}$ is created. The rural settlements in each buffer form a composite map that is considered to be the same rural settlement unit.

The composite rural settlement unit is spatially superimposed with four different distances of soil erosion. The four ranges are less than $1000 \mathrm{~m}, 1000$ to $2000 \mathrm{~m}, 2000$ to $3000 \mathrm{~m}$, and $3000 \mathrm{~m}$ or more. The erosion of the four distance segments will be obtained. The soil erosion map of three years and four distances is shown in Figures 4, 5 and 6.

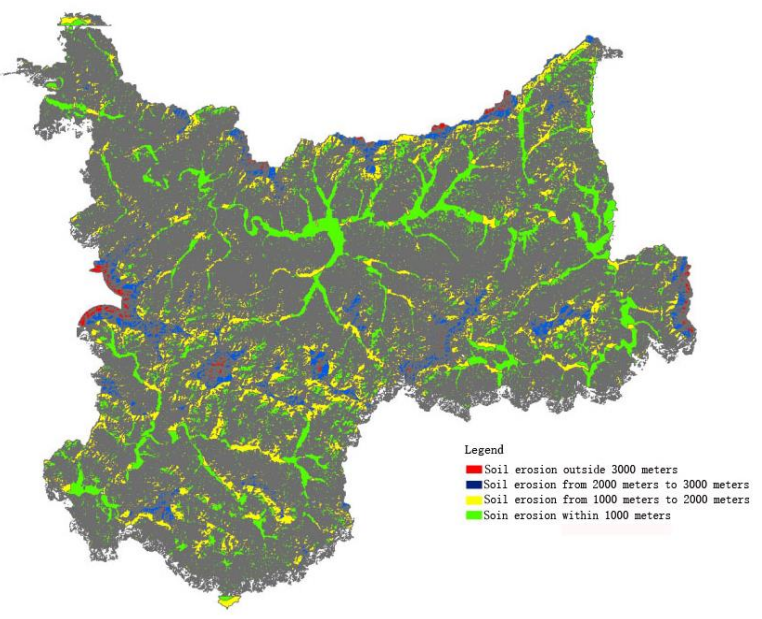

Figure 4. Soil in various buffer zones in 1992

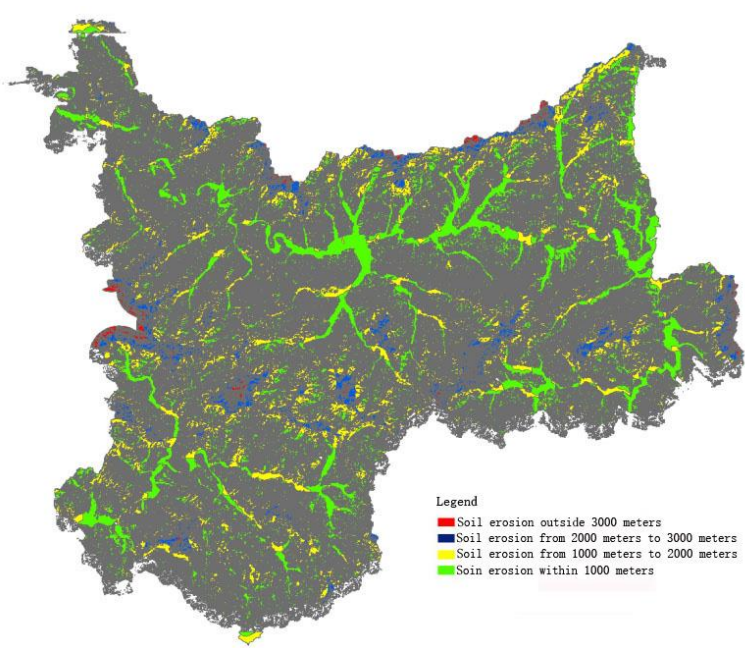

Figure 5. Soil erosion in various buffer zones in 2001 


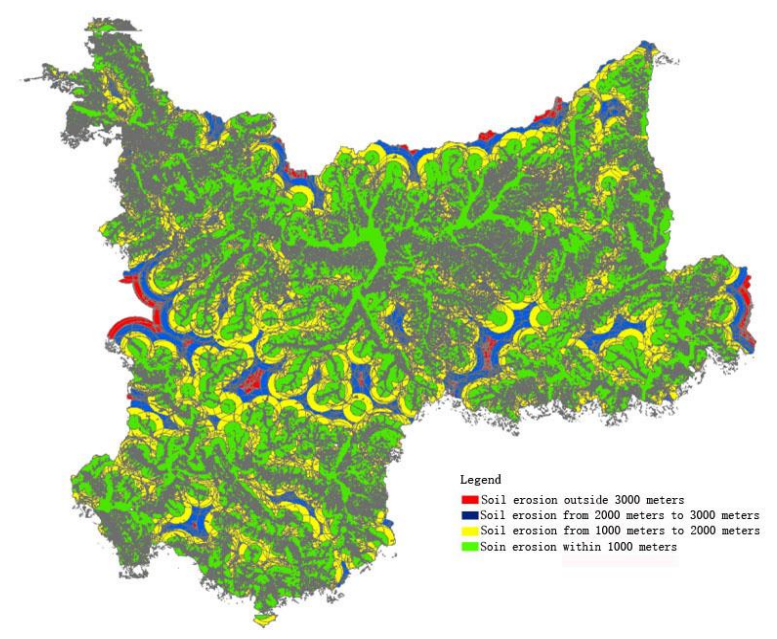

Figure 6. Soil erosion in various buffer zones in 2010

\section{Results and analysis}

\section{Analysis on the quantity structure of rural settlements in Xinbin County}

According to the analysis, at the end of 2010, Xinbin County had a total rural population of 219,805 , with a total rural settlement of $6705.7 \mathrm{hm}^{2}$ and a per construction land area of $305 \mathrm{~m}^{2} /$ person, exceeding the $150 \mathrm{~m}^{2} /$ person specified in China's "Village and Town Planning Standards" (GB50188-93). In other words, the intensive land consolidation in Xinbin County is not enough, which means there is great potential for consolidation. The largest rural settlement area is Yongling town with $939.88 \mathrm{hm}^{2}$, followed by Xinbin town of $732.88 \mathrm{hm}^{2}$. While the smallest is Xiangshuihezi Township, which is $207.32 \mathrm{hm}^{2}$. The township with the largest per capita area is Muqi town with $431.3 \mathrm{~m}^{2} /$ person. The smallest is Wangqingmen Town with only $227.32 \mathrm{~m}^{2} /$ person. The largest population is Yongling Town, with 27,854 people. The least one is Hongsheng Town, with 7464 people. The rural settlement appears as a single entity on the map, not contiguous. The map is severely fragmented, and it is in a dilapidated state with a scattered layout.

\section{Analysis of spatial distribution landscape index of rural settlement}

According to Table 2, it can be seen that the number of plaques in Yongling Town is the highest, that is, 473, indicating a high degree of fragmentation. The least is Xiangshuihezi Township, which is 97, showing that its rural settlement is relatively complete. The total area of plaque in Yongling Town is $940 \mathrm{hm}^{2}$ while the smallest is Xiangshuihezi Township, which is $207 \mathrm{hm}^{2}$. The average plaque area in Nanzamu Town is the largest, which is $3.07 \mathrm{hm}^{2} /$ per, representing that the average land use size of rural settlements is large. The average plaque area of Muqi Town is the smallest, $1.97 \mathrm{hm}^{2} /$ per, indicating that the average land use size is small. In terms of plaque density, Muqi Town is the largest one, with 0.51 number $/ \mathrm{hm}^{2}$, which indicates that the degree of fragmentation in Muqi Town is higher. The density of plaques in Nanzamu Town and Xiajiahe Town is the smallest, 0.33 number $/ \mathrm{hm}^{2}$, showing that Nanzamu Town and Xiajiahe Town are relatively complete. Beisiping Township has the largest dispersion, which is 3.98. That implies that the distribution of rural settlements in there is scattered. Yongling Town has the smallest dispersion, suggesting that the rural 
settlements in there are densely distributed. The main reason is affected by the selfsufficient economy in rural areas. In order to obtain the food needed for subsistence, farmers must have a certain amount of cultivated land. Especially in the mountainous areas of eastern Liaoning, the cultivated land resources are scarce. For the facility of farming, the scattered distribution of rural residential areas is an inevitable form. Townships with small rural settlements include Yongling Town, Xinbin Town and Nanzamu Town, which are located at the bottom of the main river and its tributaries. These places are low-lying and flat places. To a certain extent, the dispersion of rural settlements is a reflection of the impact of human activity intensity on landscape structure. Usually, if the average plaque area of the artificial landscape is small, the number of plaques will be less. Therefore, the greater the degree of separation is done, the plaque is dispersed. The separation between the natural landscape and the seminatural landscape is small, mainly because the distance between the same plaques is short or concentrated.

Table 2. Landscape index table of rural settlements land in towns and villages of Xinbin County

\begin{tabular}{c|c|c|c|c|c|c|c}
\hline Administrative unit & Coordinate & $\begin{array}{c}\mathbf{N P} \\
(\mathbf{n u m b e r})\end{array}$ & $\begin{array}{c}\mathbf{T A} \\
\left(\mathbf{h m}^{\mathbf{2}}\right)\end{array}$ & $\begin{array}{c}\mathbf{M P S} \\
\left(\mathbf{h m}^{2} \mathbf{p e r}\right)\end{array}$ & $\begin{array}{c}\mathbf{P D} \\
\left(\mathbf{n u m b e r} / \mathbf{h m}^{2}\right)\end{array}$ & RC & AWMPFD \\
\hline Beisiping town & $125^{\circ} 10^{\prime} \mathrm{E}, 41^{\circ} 47^{\prime} \mathrm{N}$ & 109 & 236 & 2.17 & 0.46 & 3.98 & 1.1369 \\
Dasiping town & $124^{\circ} 43^{\prime} \mathrm{E}, 41^{\circ} 19^{\prime} \mathrm{N}$ & 172 & 487 & 2.83 & 0.35 & 2.34 & 1.1282 \\
Hongmiaoz town & $125^{\circ} 08^{\prime} \mathrm{E}, 41^{\circ} 31^{\prime} \mathrm{N}$ & 135 & 387 & 2.87 & 0.35 & 3.78 & 1.1419 \\
Hongsheng town & $125^{\circ} 7^{\prime} \mathrm{E}, 42^{\circ} 12^{\prime} \mathrm{N}$ & 105 & 211 & 2.01 & 0.50 & 3.56 & 1.1378 \\
Muqi town & $124^{\circ} 38^{\prime} \mathrm{E}, 41^{\circ} 47^{\prime} \mathrm{N}$ & 349 & 689 & 1.97 & 0.51 & 2.69 & 1.1198 \\
Nanzamu town & $124^{\circ} 25^{\prime} \mathrm{E}, 41^{\circ} 58^{\prime} \mathrm{N}$ & 147 & 451 & 3.07 & 0.33 & 1.98 & 1.1168 \\
Pingdingshan town & $124^{\circ} 46^{\prime} \mathrm{E}, 41^{\circ} 25^{\prime} \mathrm{N}$ & 170 & 497 & 2.92 & 0.34 & 2.54 & 1.1368 \\
Shangjiahe town & $124^{\circ} 30^{\prime} \mathrm{E}, 41^{\circ} 56^{\prime} \mathrm{N}$ & 180 & 411 & 2.28 & 0.44 & 2.78 & 1.1408 \\
Wangqingmen town & $125^{\circ} 18^{\prime} \mathrm{E}, 41^{\circ} 41^{\prime} \mathrm{N}$ & 148 & 332 & 2.24 & 0.45 & 2.02 & 1.1265 \\
Weiziyu town & $124^{\circ} 31^{\prime} \mathrm{E}, 41^{\circ} 26^{\prime} \mathrm{N}$ & 139 & 380 & 2.73 & 0.37 & 2.43 & 1.1247 \\
Xiajiahe town & $124^{\circ} 26^{\prime} \mathrm{E}, 41^{\circ} 23^{\prime} \mathrm{N}$ & 115 & 346 & 3.01 & 0.33 & 3.06 & 1.1296 \\
Xiangshuihezi town & $125^{\circ} 22^{\prime} \mathrm{E}, 41^{\circ} 37^{\prime} \mathrm{N}$ & 97 & 207 & 2.13 & 0.47 & 3.23. & 1.1309 \\
Xinbin town & $125^{\circ} 26^{\prime} \mathrm{E}, 41^{\circ} 45^{\prime} \mathrm{N}$ & 309 & 733 & 2.37 & 0.42 & 1.73 & 1.0895 \\
Yongling town & $124^{\circ} 50^{\prime} \mathrm{E}, 41^{\circ} 43^{\prime} \mathrm{N}$ & 473 & 940 & 1.99 & 0.50 & 1.56 & 1.1034 \\
Yushu town & $124^{\circ} 50^{\prime} \mathrm{E}, 41^{\circ} 39^{\prime} \mathrm{N}$ & 155 & 397 & 2.56 & 0.39 & 4.12 & 1.1383 \\
Xinbin county & $125^{\circ} 02^{\prime} \mathrm{E}, 41^{\circ} 44^{\prime} \mathrm{N}$ & 2803 & 6706 & 2.39 & 0.42 & 2.42 & 1.1327 \\
\hline
\end{tabular}

Related studies have shown that the rural settlements as artificial plaques have greater stability and small fractal dimension, and the formed plaques are not prone to change. This leads to an increase in the heterogeneity of the natural plaque landscape around it. The fractal dimension is larger than the artificial plaque, and the landscape tends to be unstable. The area-weighted average patch fractal dimension represents the complexity of the margin of land-use plaque at a certain research scale, generally between 1 and 2 . The closer the value is to 1 , the stronger the self-similarity of the plaque. The smaller the ratio of the length to the axis, the more regular the shape of the plaque, and the shape of the plaque is close to a circle or a square. This shows that the greater the degree of human interference. Because plaques formed by human interference are generally more regular in shape, similar plaque shapes are prone to occur. The larger the value of the area-weighted average patch fractal dimension, the 
larger the ratio of the length to the short axis. At the same time, the more complex the shape of the plaque, the narrower the geometry of the plaque and the less interference it receives (Cheng, 2016; Yang et al., 2018). The weighted average patch fractal dimension of rural settlement areas in Xinbin County is below 1.16, which is close to 1. This is because the rural settlement plaque belongs to the artificial landscape plaque, the plaque shape is relatively regular, close to the square, and the stability is strong. Xinbin Town has the smallest area-weighted average patch fractal dimension of 1.1034. The largest in Hongmiaozi Township is 1.1419. The values of rural towns and villages are all below 1.5, indicating that these rural township settlements are not in a random state similar to Brownian motion but in a steady state.

\section{Analysis of spatial distribution landscape index of rural settlement}

This paper selects soil erosion to reflect the water conservation status of the study area.

\section{Analysis of current situation of soil erosion in Xinbin County}

It can be seen from Table 3 that at present, the farmland erosion is the most serious with the total erosion area of $37,768.73 \mathrm{hm}^{2}$. The severe erosion is $472.75 \mathrm{hm}^{2}$, accounting for $1.25 \%$ of the farmland. The proportion of middle degree erosion in farmland is $49.33 \%$. The least eroded is the unutilized land. This means that measures must be taken to control soil erosion. If the treatment effect on soil erosion is good, such a large proportion of eroded land will decrease. It will convert into light erosion land. From the perspective of the total erosion area, the woodland is second behind the farmland, with an area of $3457.33 \mathrm{hm}^{2}$. This is because Xinbin county has a relatively large coverage of forest land. The excessive base and the artificial interference in the woodland have caused the erosion area. Being located in the mountainous area, protecting the water and soil means protecting the forest land in Xinbin county.

Table 3. Soil erosion status statistics within $1000 \mathrm{~m}$ in rural settlements in 2010

\begin{tabular}{|c|c|c|c|c|c|}
\hline & $\begin{array}{c}\text { Farmland } \\
\left(\mathbf{h m}^{2}\right)\end{array}$ & $\begin{array}{l}\text { Woodland } \\
\left(\mathbf{h m}^{2}\right)\end{array}$ & $\begin{array}{c}\text { Grassland } \\
\left(\mathbf{h m}^{2}\right)\end{array}$ & $\begin{array}{l}\text { Garden land } \\
\qquad\left(\mathrm{hm}^{2}\right)\end{array}$ & $\begin{array}{c}\text { Unutilized land } \\
\left(\mathbf{h m}^{2}\right)\end{array}$ \\
\hline Light erosion & 3148 & 15152 & 340.42 & 213.11 & 10.64 \\
\hline Middle degree & 18634.05 & 13129 & 786.51 & 262.49 & 15.12 \\
\hline Serious erosion & 12232.64 & 4853.6 & 415.2 & 96.84 & 8.35 \\
\hline Very intensive & 3281.29 & 1263.4 & 100.75 & 25.67 & 1.76 \\
\hline Severe erosion & 472.75 & 175.33 & 17 & 4.73 & 0 \\
\hline
\end{tabular}

\section{Relationship between soil erosion and rural settlement distance}

From Table 4, soil erosion was the most severe in 2001 during the three periods, with an erosion rate of $57 \%$. The soil erosion in 2010 was the lightest with an erosion rate of $39.87 \%$. Ranking in the middle place, the soil erosion rate in 1992 is $55.34 \%$. From the point of view of the buffer zone of $1000 \mathrm{~m}$, it was also the most severe erosion in 2001, with an erosion of $39.06 \%$. The rate in 1992 was similar to that in 2001. Compared with 2010, the soil erosion in these two periods was more serious. Because the rural settlement in these two periods had a low degree of concentration and a more dispersed distribution. At the same time, the degree of land use was also low, making erosion 
more serious. Afterwards, with the improvement of living conditions and the guidance of policies such as the revitalization of the Chinese government, the concentration of rural settlement increased, the average plaque area grew, and the intensity of human activities rose, but the density of plaques became larger. The degree of utilization has been improved, and soil erosion has been alleviated to some extent, therefore, the soil erosion rate is lower in 2010 than that of the other two years.

Table 4. Statistical table of soil erosion at different distances in three time periods

\begin{tabular}{c|c|c|c|c}
\hline \multirow{2}{*}{ Years } & \multicolumn{4}{|c}{ Distance/m } \\
\cline { 2 - 5 } & $<\mathbf{1 0 0 0}$ & $\mathbf{1 0 0 0 - 2 0 0 0}$ & $\mathbf{2 0 0 0 - 3 0 0 0}$ & $>\mathbf{3 0 0 0}$ \\
\hline Erosion rate in 1992 & $38.49 \%$ & $12.44 \%$ & $2.20 \%$ & $2.21 \%$ \\
Erosion rate in 2001 & $39.06 \%$ & $12.81 \%$ & $2.39 \%$ & $2.74 \%$ \\
Erosion rate in 2010 & $21.26 \%$ & $16.59 \%$ & $1.79 \%$ & $0.23 \%$ \\
\hline
\end{tabular}

The soil erosion in the three time periods is gradually decreasing as the distance from the rural settlement increases. This shows that the distribution of rural settlements has a certain impact on soil erosion. Taking 2010 as an example, the erosion rate is $21.26 \%$ within $1000 \mathrm{~m}$, and the erosion rate is $16.59 \%$ from 1000 to $2000 \mathrm{~m}$. Because human activities are dependent on land. The closer the rural settlement is, the greater the intensity of human activity, thereby, the erosion is more serious.

\section{Relationship between erosion intensity and rural settlements structure}

Table 5 shows the landscape index under different erosion intensities, that is, the different structure of rural settlements under different erosion intensities. Based on the data in Table 5, the grey correlation analysis of erosion intensity and the rural settlement structure was carried out by using spss16.0 software, and Table 6 was obtained. It can be seen from Table 6 that there is a correlation between soil erosion intensity and the rural settlement structure. The degree of correlation is AWMPFD $>$ PD $>$ NP $>$ RC. From the positive effects of correlation degree, the correlation between AWMPFD, MPS, NP, RC and the soil erosion intensity are positive. In other words, the larger the above indicators, the greater the soil erosion intensity. The larger the value of NP and $\mathrm{RC}$ means that the activity range of farmers in the area is large, so the intensity of soil erosion will be severe. The more extensive the farmers use the land, the stronger the interference, and the more regular the shape of the rural settlements, the greater the erosion intensity. From the negative effects of correlation degree, the PD has a negative correlation with soil erosion intensity. The larger it is, the smaller the soil erosion intensity. As the PD value increases, the number of settlements per unit area increases, and the intensive use of land means that the soil erosion intensity may be lower.

\section{Relationship between soil erosion and population density}

Arcgis9.3 is applied to compound the map spots of Xinbin county into 33 composite map spots. Through this operation, Table 7 is obtained. Three of these different patches are eliminated. Correlation and regression analysis use spss16.0. Through this operation, Table 8 is obtained. Table 8 shows when the confidence (unilateral) is 0.01, the correlation between population density and erosion area is significant and positively correlated. Because human activities, such as farming and cutting, have aggravated the 
loss of water and soil, making the erosion area larger. In the protection of water and soil, human influence must be considered.

It can be seen from Table 9 that there is no relationship between soil erosion intensity and population density. And among the 30 plots, almost every plot has the largest area of middle degree erosion intensity.

Table 5. Soil erosion intensity and rural settlement structure data in 2010

\begin{tabular}{c|c|c|c|c|c}
\hline Erosion intensity & $\begin{array}{c}\text { Erosion area } \\
\left(\mathbf{h m}^{\mathbf{2}}\right)\end{array}$ & $\begin{array}{c}\mathbf{N P} \\
(\mathbf{n u m b e r})\end{array}$ & $\begin{array}{c}\mathbf{P D} \\
\left(\mathbf{n u m b e r} / \mathbf{h m}^{2}\right)\end{array}$ & $\mathbf{R C}$ & AWMPFD \\
\hline Microdegree & 149122.51 & 1227 & 317.65 & 354.76 & 1.07 \\
Light erosion & 25164.45 & 1295 & 530.76 & 677.69 & 1.05 \\
Middle degree & 43437.96 & 3293 & 120.24 & 324.13 & 1.14 \\
Serious erosion & 23154.39 & 2580 & 139.44 & 530.72 & 1.13 \\
Very intensive & 6113.52 & 1210 & 271.33 & 434.03 & 1.08 \\
Severe erosion & 874.98 & 208 & 331.58 & 105.68 & 1.06 \\
\hline
\end{tabular}

Table 6. Correlation between erosion intensity and rural settlement structure in 2010

\begin{tabular}{c|c}
\hline & Grey correlation \\
\hline NP (number) & 0.51 \\
PD (number $\left./ \mathrm{hm}^{2}\right)$ & -0.58 \\
RC & 0.40 \\
AWMPFD & 0.62 \\
\hline
\end{tabular}

Table 7. Soil erosion in different blocks of Xinbin County

\begin{tabular}{c|c|c|c|c|c|c|c|c|c|c}
\hline Plot & $\mathbf{1}$ & $\mathbf{2}$ & $\mathbf{3}$ & $\mathbf{4}$ & $\mathbf{5}$ & $\mathbf{6}$ & $\mathbf{7}$ & $\mathbf{8}$ & $\mathbf{9}$ & $\mathbf{1 0}$ \\
\hline $\begin{array}{c}\text { Erosion area }\left(\mathrm{m}^{2}\right) \\
\begin{array}{c}\text { Population density } \\
\left(\text { person } / \mathrm{km}^{2}\right)\end{array}\end{array}$ & 45587.56 & 20420.79 & 135.06 & 309.13 & 76.74 & 1216.6 & 466.18 & 105.28 & 147 & 83.55 \\
\hline Plot & $\mathbf{1 1}$ & $\mathbf{1 2}$ & $\mathbf{1 3}$ & $\mathbf{1 4}$ & $\mathbf{1 5}$ & $\mathbf{1 6}$ & $\mathbf{1 7}$ & $\mathbf{1 8}$ & $\mathbf{1 9}$ & $\mathbf{2 0}$ \\
\hline $\begin{array}{c}\text { Erosion area }\left(\mathrm{m}^{2}\right) \\
\begin{array}{c}\text { Population density } \\
\left(\text { person } / \mathrm{km}^{2}\right)\end{array}\end{array}$ & 164.56 & 779.41 & 15372.25 & 237.97 & 156.59 & 292.57 & 112.88 & 88.73 & 222.21 & 47.67 \\
\hline Plot & $\mathbf{2 1}$ & $\mathbf{2 2}$ & $\mathbf{2 3}$ & $\mathbf{2 4}$ & $\mathbf{2 5}$ & $\mathbf{2 6}$ & $\mathbf{2 7}$ & $\mathbf{2 8}$ & $\mathbf{2 9}$ & $\mathbf{3 0}$ \\
\hline $\begin{array}{c}\text { Erosion area }\left(\mathrm{m}^{2}\right) \\
\text { Population density } \\
\left(\text { person } / \mathrm{km}^{2}\right)\end{array}$ & 25.04 & 7.3 & 14.38 & 6.08 & 5.45 & 8.85 & 0.56 & 46.42 & 19.44 & 47.38 \\
\hline
\end{tabular}

Table 8. Nonparametric correlation coefficient analysis

\begin{tabular}{c|c|c|c}
\hline & & Population density & Erosion area \\
\hline \multirow{3}{*}{ Population density } & Correlation coefficient & 1.000 & $.734^{* *}$ \\
& Sig. (unilateral) &. & .000 \\
& $\mathrm{~N}$ & 30 & 30 \\
\hline \multirow{3}{*}{ Erosion area } & Correlation coefficient & $.734^{* *}$ & 1.000 \\
& Sig. (unilateral) & .000 &. \\
& $\mathrm{~N}$ & 30 & 30 \\
\hline
\end{tabular}


Table 9. Statistical data of soil erosion intensity of 30 typical plots

\begin{tabular}{|c|c|c|c|c|c|c|}
\hline Plot & $\begin{array}{c}\text { Light } \\
\text { erosion } \\
\left(\mathbf{m}^{2}\right) \\
\end{array}$ & $\begin{array}{c}\text { Middle } \\
\text { degree } \\
\left(\mathbf{m}^{2}\right)\end{array}$ & $\begin{array}{c}\text { Serious } \\
\text { erosion } \\
\left(\mathbf{m}^{2}\right)\end{array}$ & $\begin{array}{c}\text { Very } \\
\text { intensive } \\
\left(\mathbf{m}^{2}\right)\end{array}$ & $\begin{array}{c}\text { Severe } \\
\text { erosion } \\
\left(\mathbf{m}^{2}\right)\end{array}$ & $\begin{array}{c}\text { Population } \\
\text { density } \\
\left(\text { person } / \mathbf{k m}^{2}\right)\end{array}$ \\
\hline 26 & 6.33 & 2.25 & 0.18 & 0.09 & 0 & 8600 \\
\hline 27 & 0.56 & 0 & 0 & 0 & 0 & 8900 \\
\hline 28 & 19.41 & 17.98 & 7.35 & 1.41 & 0.27 & 9000 \\
\hline 29 & 13.62 & 5.82 & 0 & 0 & 0 & 9000 \\
\hline 25 & 3.1 & 2.35 & 0 & 0 & 0 & 9100 \\
\hline 23 & 10.18 & 3.84 & 0.27 & 0.09 & 0 & 9200 \\
\hline 22 & 4.76 & 2.27 & 0.27 & 0 & 0 & 9300 \\
\hline 24 & 5.09 & 0.81 & 0.18 & 0 & 0 & 9300 \\
\hline 30 & 18.67 & 24.03 & 4.14 & 0.54 & 0 & 18100 \\
\hline 20 & 15.48 & 19.8 & 9.6 & 2.61 & 0.18 & 26400 \\
\hline 3 & 30.62 & 54.73 & 42.32 & 7.39 & 0 & 85300 \\
\hline 14 & 125.62 & 82.4 & 23.11 & 6.21 & 0.63 & 93200 \\
\hline 17 & 29.89 & 40.56 & 36.94 & 5.49 & 0 & 144300 \\
\hline 18 & 31.52 & 31.74 & 15.21 & 6.75 & 3.51 & 283600 \\
\hline 7 & 98.71 & 187.42 & 129.9 & 44.43 & 5.72 & 397500 \\
\hline 9 & 26.36 & 54.36 & 41 & 23.48 & 1.8 & 412900 \\
\hline 4 & 79.01 & 159.32 & 47.65 & 17.25 & 5.9 & 475100 \\
\hline 10 & 14.35 & 31.27 & 27.94 & 9.45 & 0.54 & 503500 \\
\hline 19 & 57.72 & 131.4 & 29.94 & 3.15 & 0 & 555100 \\
\hline 13 & 3675.23 & 7217.92 & 3453.17 & 905.93 & 120 & 559000 \\
\hline 16 & 82.22 & 114.55 & 71.41 & 22.59 & 1.8 & 574200 \\
\hline 5 & 25.03 & 30.81 & 15.75 & 4.88 & 0.27 & 576900 \\
\hline 11 & 40.38 & 63.07 & 35.55 & 21.78 & 3.78 & 597800 \\
\hline 12 & 361.06 & 378.65 & 35.34 & 4 & 0.36 & 616200 \\
\hline 6 & 202.89 & 525.71 & 376.05 & 98.62 & 13.33 & 647900 \\
\hline 8 & 24.13 & 44.4 & 28.62 & 7.68 & 0.45 & 669800 \\
\hline 15 & 85.76 & 101.94 & 56.89 & 13.13 & 0.81 & 793500 \\
\hline 21 & 12.8 & 7.74 & 3.33 & 0.99 & 0.18 & 866500 \\
\hline 2 & 3917.5 & 8771.43 & 5590.28 & 1805.09 & 336.49 & 921800 \\
\hline 1 & 10467.94 & 20607.06 & 11501.62 & 2685.41 & 325.53 & 1193900 \\
\hline
\end{tabular}

\section{Relationship between soil erosion and the size of rural settlements}

In the same way, the spss16.0 software is used to analyze the correlation between soil erosion and the size of rural settlements. The results show that soil erosion is highly correlated with the size of rural settlements and is positively correlated. This means that the greater the size of the rural settlement, the more serious the erosion. Therefore, rural settlements should be determined to a reasonable scale to prevent soil erosion. Spss16.0 is applied to analyze the correlation between rural settlement size and erosion grade (severe erosion as a percentage of erosion area). The results show that the erosion intensity is not related to the size of the settlement. This suggests that the larger the rural settlement, the more serious the erosion, but the erosion intensity is not necessarily severe. 


\section{Discussion}

In terms of the features of the rural settlement itself, the rural settlement area gradually decreases with the elevated altitude. Among them, the rural settlement with the elevation of $121-345 \mathrm{~m}$ is the largest, accounting for $50.33 \%$ of the total area of rural settlements. There are no rural settlements above $734 \mathrm{~m}$. The land use and spatial distribution of rural settlements are influenced by both natural and human factors. Generally, mountainous and hilly areas are significantly affected by natural geographical factors (altitude, slope, aspect, etc.) (Li-Bang et al., 2018; Guo et al., 2012). From the statistics of the rural settlement area at different altitudes within the entire rural settlement, it can be seen that with the rise of altitude, the scale of rural settlements is getting smaller and smaller. The population density is small, and the spatial distribution of rural settlements is random (Yang et al., 2016). According to the results of the slope analysis, the rural settlements in Xinbin county are mainly distributed on the flat land of $0^{\circ}-5^{\circ}$ and hilly-sloppy lands of $8^{\circ}-15^{\circ}$. Its rural settlement area accounts for $21.25 \%$ and $28.55 \%$ of the total rural settlement area of the county. Ren (2017) also pointed out in one of his articles. The spatial distribution of rural settlements showed some spatial orientation to low altitude and to low slope, and were significantly close to rivers and towns; thus formed a special pattern of "dense on the plains, and sparse in the mountainous region" (Ren, 2017). However, in the Xinbin county, there are still a large number of peasants living in areas with slopes greater than $15^{\circ}$, which increases the difficulty of ecological management. For such rural settlements, ecological migration should be considered.

From the perspective of landscape pattern analysis (Wenzhi, 2016), Xinbin county, located in the mountainous area of Liaodong, is affected by various natural and social factors, especially the long-term self-sufficient lifestyle and topographical factors that result in insufficient per capita arable land (Zhou et al., 2013). The situation of rural residential areas in the county include the following aspects: the average plaque area of the landscape features is small; the number of plaques is large; the per capita land area exceeds the standard; the average phenotypic fractal dimension is small, and most townships are small in scale. This reveals that the plaque has a certain stability and dispersion. It is the scattered landscape pattern of rural settlements and the stability of the county as artificial landscape patches, which makes the area of human disturbance to the surrounding natural ecological environment expand continuously, and the fragmentation of natural landscape patches is bound to intensify. This leads to an increase in soil erosion and destruction of the ecological environment in a small area.

In addition, when the confidence level is 0.01 , the soil erosion in the study area is significantly correlated with the size and population density of the rural, and it is a positive correlation. The erosion intensity is not related to the size of the settlement. This shows that the larger the rural settlement, the more serious the erosion, but the erosion intensity is not necessarily severe, and human activities will increase the erosion area. Therefore, the distribution of rural settlements must reach a reasonable scale to maximize economic and ecological benefits. At the same time, the study found that soil erosion showed a decreasing trend with increasing distance (Gan et al., 2014), because human activities need to rely on the land. In the place closer to the rural settlement, the greater the intensity of human activity, the more serious the erosion. From the perspective of rural settlement structure, erosion intensity is positively correlated with NP, RC and AWMPFD. This shows that the more dispersed the rural settlements, the more extensive the use, the more human disturbance, the stronger the erosion intensity. 
On the contrary, PD is negatively correlated with soil erosion intensity, which indicates that the more the rural settlements gather, the higher the utilization degree, the lower the erosion intensity. Therefore, it is necessary to consider improving and strengthening the spatial agglomeration of rural settlements, thereby reducing the intensity of soil erosion.

The spatial distribution characteristics of rural settlements reflect the relationship between human production, life and its surrounding environment under different productivity levels. The landscape pattern of rural settlements and its dynamic changes affect many environmental factors, such as water and soil conservation, topography and so on. How to change the landscape pattern and spatial distribution of the current rural settlements in Xinbin county and even the entire Liaodong mountainous area, so that its ecological environment protection is in the most reasonable state? One of the most effective ways is to study the landscape pattern of rural settlements and its distribution characteristics, namely ecological migration.

\section{Conclusion}

Rural settlements are places where people live and move in mountainous areas. The denser the distribution of settlements, the greater the intensity of people's activities. The rational distribution of rural settlements will contribute to soil and water conservation in the region. Otherwise, it will aggravate soil erosion. At present, the layout of rural settlements in China is relatively poor. The analysis of the rational distribution of rural settlements does not consider the impact of the distribution of rural settlements on soil erosion. This paper takes Xinbin county, Liaoning province, China as an example, using remote sensing technology, ArcGIS and Fragstats 3.3 softwares. Based on the remote sensing satellite and land use status map, the landscape pattern of residential area distribution and soil erosion status in three time periods are analyzed. Via the correlation analysis method, the relationship between the distribution characteristics of rural settlements and soil erosion is quantitatively analyzed. The following is the main conclusion.

(1) In general, the proportion of rural settlement land use in Xinbin county is relatively small. The MPS of rural residential patches is small, the degree of land use is not high, the degree of separation is high, and the distribution of settlements is scattered and chaotic, mostly distributed along rivers and traffic roads.

(2) In three periods, soil erosion was the most serious in 2001, with an erosion rate of $57 \%$; in 2010, soil erosion was the least, with an erosion rate of $39.87 \%$. The intermediate soil erosion rate in 1992 was 55.34\%.

(3) Soil erosion is positively correlated with population density and the size of rural settlements. However, the intensity of erosion is not related to the size of the settlement. Soil erosion shows a decreasing trend with increasing distance. From the perspective of rural settlement structure, erosion intensity is positively correlated with NP, RC and AWMPFD. On the contrary, PD is negatively correlated with soil erosion intensity.

Acknowledgments. The study is supported by the Fund Project of Shaanxi Key Laboratory of Land Consolidation (2019-ZD05). 


\section{REFERENCES}

[1] Allen, D. W. (2016): GIS Tutorial 2: Spatial Analysis Workbook. - Esri Press, Redlands, CA.

[2] Chaolin, G. U., Weihua, G., Helin, L. (2017): Chinese urbanization 2050: SD modeling and process simulation. - Science China (Earth Sciences) 06: 57-72.

[3] Chen, L., Sun, R., Lv, Y. (2018): A Landscape Index to link landscape pattern with nutrient loss at watershed scale. - AGU Fall Meeting Abstracts. American Geophysical Union, Washington, DC.

[4] Chen, Y., Ge, Y. (2015): Spatial point pattern analysis on the villages in China's povertystricken areas. - Procedia Environmental Sciences 27: 98-105.

[5] Cheng, X. (2016): Analysis on the relationship between degree of fragmentation and production profits of arable landscapes upon varying landforms - a case study of Xinjian County, Jiangxi Province. - Agricultural Science \& Technology 17(8).

[6] Christensen, A. A., Brandt, J., Svenningsen, S. R. (2016): Landscape Ecology. - In: Richardson, D. et al. (eds.) International Encyclopedia of Geography: People, the Earth, Environment and Technology. Wiley, Hoboken, NJ, pp. 1-10.

[7] Conrad, C., Rudloff, M., Abdullaev, I., Thiel, M., Löw, F., Lamers, J. P. A. (2015): Measuring rural settlement expansion in Uzbekistan using remote sensing to support spatial planning. - Applied Geography 62: 29-43.

[8] Cronk, B. C. (2017): How to Use SPSS®: A Step-by-Step Guide to Analysis and Interpretation. - Routledge, New York.

[9] Gan, C., Li, Y., Wang, Y., Shao, J. (2014): Analysis of the spatial distribution character and its soil erosion of rural settlement in the center region of the Three Gorges Reservoir Area-a case study of 27 towns of Fengjie County. - Journal of Chongqing Normal University 31(4): 52-58.

[10] Gandhi, G. M., Parthiban, S., Thummalu, N., Christy, A. (2015): NDVI: vegetation change detection using remote sensing and GIS - a case study of Vellore District. Procedia Computer Science 57: 1199-1210.

[11] Green, S. B., Salkind, N. J. (2016): Using SPSS for Windows and Macintosh, Books a la Carte. - Pearson, London.

[12] Guo, X. D., Zhang, Q. Y., Ma, L. B. (2012): Analysis of the spatial distribution character and its influence factors of rural settlement in transition-region between mountain and hilly. - Econ. Geogr 32(10).

[13] Ju, J., Masek, J. G. (2016): The vegetation greenness trend in Canada and US Alaska from 1984-2012 Landsat data. - Remote Sensing of Environment 176: 1-16.

[14] Ke, Y. (2016): Based on ENVI optimization of automatic interpretation of remote sensing image classification results. - World Nonferrous Metals 2016: 59.

[15] Li-Bang, M. A., Ya-Ya, T., Xiao-Dong, G., Mei-Mei, C., Yong-Li, W. (2018): Spatialtemporal change of rural settlements and its spatial coupling relationship with water and soil resources based on grid in the Hexi oasis. - Journal of Natural Resources 33(5): 775787.

[16] Ma, Y. Q., Shi, Y., Qin, Y. W., Zheng, B. H., Zhao, Y. M., Zhang, L. (2014): Temporalspatial distribution and pollution assessment of heavy metals in the upper reaches of Hunhe River (Qingyuan section), Northeast China. - Huan Jing Ke Xue 35(1): 108-116.

[17] Maguire, D. J. (2015): ArcGIS: General-Purpose GIS Software. - In: Shekhar, S. et al. (eds.) Encyclopedia of GIS. Springer, Basel, pp. 1-8.

[18] Murasingh, S., Jha, R., Adamala, S. (2018): Geospatial technique for delineation of groundwater potential zones in mine and dense forest area using weighted index overlay technique. - Groundwater for Sustainable Development 7: 387-399.

[19] Remmel, T. K., Fortin, M. J. (2017): What Constitutes a Significant Difference in Landscape Pattern? - In: Gergel, S. E. Turner, M. G. (eds.) Learning Landscape Ecology. - Springer, New York, pp. 105-125. 
[20] Ren, Y. (2017): An analysis of rural settlement patterns and their effect mechanisms based on road traffic accessibility of Guangdong. - Acta Geographica Sinica 72(10): 1859-1871.

[21] Rodríguez-Loinaz, G., Alday, J. G., Onaindia, M. (2015): Multiple ecosystem services landscape index: a tool for multifunctional landscapes conservation. - Journal of Environmental Management 147: 152-163.

[22] Segatori, A., Marcelloni, F., Pedrycz, W. (2017): On distributed fuzzy decision trees for big data. - IEEE Transactions on Fuzzy Systems 26(1): 174-192.

[23] Wenzhi, T. (2016): Rural landscape planning and design based on the perspective of beautiful rural construction. - Chinese Journal of Agricultural Resources \& Regional Planning 37(09):229-232.

[24] Xi, H., Xiao, L., Liu, R. Q., Yu, M. M. (2018): Evolution characteristics and driving mechanism of rural settlement in the fringe belt of famous historical and cultural city: taking Hancheng Miaohou village of Shaanxi province for example. - Areal Research \& Development 37(2): 158-162.

[25] Yang, R., Liu, Y., Long, H., Qiao, L. (2015): Spatio-temporal characteristics of rural settlements and land use in the Bohai Rim of China. - Journal of Geographical Sciences 25(5): 559-572.

[26] Yang, R., Xu, Q., Long, H. (2016): Spatial distribution `characteristics and optimized reconstruction analysis of China's rural settlements during the process of rapid urbanization. - Journal of Rural Studies 47(47): 413-424.

[27] Yang, Y., Liu, Y., Li, Y., Du, G. (2018): Quantifying spatio-temporal patterns of urban expansion in Beijing during 1985-2013 with rural-urban development transformation. Land Use Policy 74: 220-230.

[28] Ying, T. (2017): Evaluation of water ecological health of Hunhe River by using diatom index. - Water Resources \& Hydropower of Northeast China 5: 19.

[29] Ying, X., Jian-Rong, F., Lei-Lei, L. I., Xuan, L. I. (2017): Comparisons on sparse alpine grassland based on vegetation coverage inversion models of remote sensing. - Journal of Sichuan Agricultural University 35(01): 37-59.

[30] Zhou, G., He, Y., Tang, C., Yu, T., Xiao, G., Zhong, T. (2013): Dynamic mechanism and present situation of rural settlement evolution in China. - Journal of Geographical Sciences 23(3): 513-524. 